\title{
The Effect Of Gross Capital Formation Toward Gross Domestic Products: State Analysis
}

\author{
Lidiana \\ \{Nanaanda2@gmail.com\}
}

STMIK Indonesia Banda Aceh, Indonesia

\begin{abstract}
This study aims to determine the effect of Gross Capital Formation (Gross Capital Formation), om of Gross Domestic Product in the countries, and per capita income groups. The data used in this study is a secondary data sourced from World Development Indicators, World Bank, The Heritage Foundation, and The Freedom House in 2012. This study uses Ordinary Least Square method with cross section data. The results of the study used three independent variables showed mixed results at the level of $\alpha=5 \%$. For the Gross Domestic Product, variable has a positive effect, Based on the analysis results, we can conclude that the diversity of the results obtained from the analysis conducted shows Gross Capital Formation, nature varies in each state and the state's per capita income brackets. This study is expected to be a reference material consideration in the planning and improvement of the Gross Domestic Product number of countries of the world.
\end{abstract}

Keywords: Gross Domestic Product, Gross Capital Formation.

\section{Introduction}

Macro economically, the increasing of Gross Domestic Product is economic growth. The economy of a country development or increase if the level of its economic activity increases or higher when it compare to the previous year, in other words, its development only occurs if the amount of goods and services produced physically in the country's economy increases in the following years.By trying to read the growth of other countries, economists who lack the implementation of the economic growth of other countries, will begin to find out the standard level of consumption enjoyed by other countries. The influence of the desire to obtain a higher standard of living will spread. As a result, countries that are less likely to increase economic growth will learn in countries that have higher rates of economic growth.

In the past few years, many empirical studies have emphasized the differentiation of the role of private capital formation and capital formation by the government in the process of economic growth of a country. Capital formation or private investment in the infrastructure sector can increase marginal products in private capital, increasing the level of economic growth of the country. Furthermore, the rapid pace of capital formation will gradually reduce the need for foreign capital. Ultimately, the increase in the rate of capital formation helps increase output, which in turn increases the rate and level of national income and a healthy and balanced economy. 


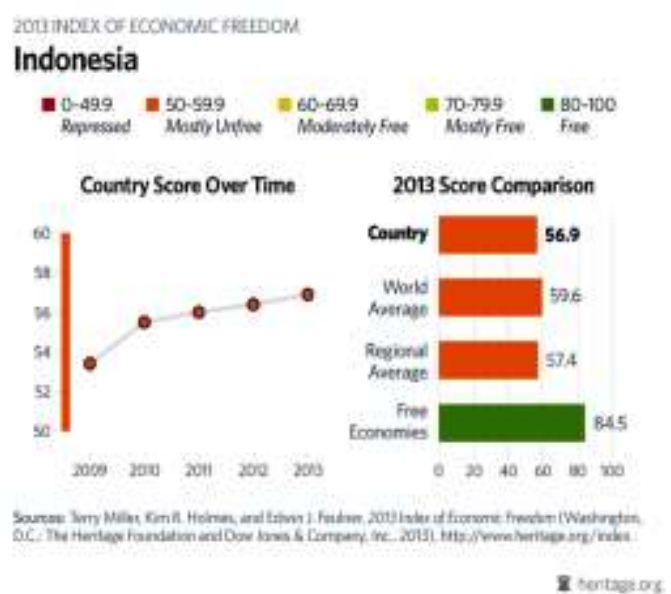

Fig. 1. Chart of the Value of the Indonesian Economic Freedom Index

From the picture, we can see that there is an increasing in economic freedom in the State of Indonesia. At the East Asia and Pacific Regional average, Indonesia is ranked 20th out of 41 countries. Overall, Indonesia in 2013 was below the average value of the world Economic Freedom Index Looking at the value of each component given in the Economic Freedom Index, The Heritage Foundation 2013, Indonesia has weaknesses in six components, namely Intellectual Property Rights Protection, Freedom of Corruption, Business Freedom, Labor Freedom, Investment Freedom and Financial Freedom. All of these components demand improvements in the system and government performance. Based on above description, the truth of hypotheses concerning Gross Capital Formation, which can affect welfare and improve the standard of living of a country is very interesting to study. On this basis, researchers are interested in examining the influence of Gross Capital Formation

\section{Research Methods}

The analytical method used is multiple regression analysis with the Ordinary Least Square (OLS) estimation method using the Shazam version 9.0 Software with an equation model on the influence of Gross Capital Formation, Economic Freedom and Political Freedom on the country's Gross Domestic Product. In this study, as the dependent variable (GDP) and Gross Capital Formation (GCF), as an independent variable and can be formulated as follows, in order to obtain the equation:

$$
P D B=f(G C F,)
$$

Based on the econometric model Cobb-Douglas at Gujarati (2004) :

$$
Y=A G C F^{a 1}
$$

From the equation (1) and (2), obtained :

$$
P D B=a_{1}+a_{2} G C F+e
$$

For the linearity of the form of equation (3), the equation uses the normal logarithm of the variable Gross Domestic Product (GDP) and the variable Gross Capital Formation (GCF), so that it is obtained: 


$$
L_{n} P D B_{i}=a_{0}+a_{1} L_{n} G C F_{i}+e_{i}
$$

where:

$$
\begin{array}{ll}
P D B_{i} & : \text { Gross Domestic Product } \\
G C F_{i} & : \text { Gross Capital Formation } \\
a_{0} & : \text { constant } \\
a_{1}, a_{2}, a_{3} & : \text { regression coefficient } \\
e_{i} & : \text { interference factor }
\end{array}
$$

\subsection{Harod-Domar Economic Growth Model}

The Harod-Domar growth model was widely used after the second World War. This model arises from the publication of articles made by Roy Harod and Evsey Domar. These two authors produced identical economic growth models because they used a simple extension of the John Maynard Keynes macroeconomic model.

As Keynesian macroeconomic model, the Harod-Domar model has the assumption that workers who have not worked are not limited in number, and output can be increased without triggering rising prices. This assumption logically leads to a constant marginal product of capital; each additional capital unit increases the final output by the same amount because freelance workers or workers are always available so that the capital-labor ratio is always constant. Output in this model is a constant function of capital stock. The value of this function is often referred to as the ratio of capital-output, which is the amount of capital needed to produce real output units in several time periods (usually annual). With a capitaloutput ratio, output growth is in line and proportional to new investment in new capital.

The Harod-Domar model has another assumption, productive investment must be maintained. So, if consumers refrain from consumption and ultimately save, then the savings become an investment project. This assumption simplifies the formula for increasing the rate of economic growth.The formal Harod-Domar model is usually made in mathematical form. Starting with assuming that economic output (Y) consists of two categories, namely consumer goods (C) and investment goods (I), then:

$$
Y=C+I
$$

Harrod-Domar stated investment with changes in capital stock, $\Delta \mathrm{K}$, where $\Delta$ is "change". If we substitute $\Delta \mathrm{K}$ with I in equation (2.2) will be obtained: $\quad Y=C+\Delta K \quad$ (2.3)

Note that this assumption is where changes in capital stock equal investment, which implies that the existing capital stock does not depreciate.

The constant assumption of capital-output ratio implies that $K / Y=\gamma$ (2.4)

$\gamma$ is constant. By moving $Y$ and $\gamma$ to the right, then the output is proportional to capital stock:

$$
Y=(1 / \gamma) K=A K
$$

If $\mathrm{A}$ is defined equal to $(1 / \gamma)$

In order for the relationship in equation (2.5) to lead to the Harod-Domar model which states that the rate of growth in output is proportional to the level of saving, the change in output is proportional to changes in capital stock, or $\Delta Y=(1 / \gamma) \Delta K=A \Delta K$

\subsection{Solow Economic Growth Model}

Robert M. Solow, in 1956 developed a model of economic growth that focuses on longterm economic growth and other things that influence it, as a comparison of short-term 
fluctuations. The Solow growth model is usually called the neoclassical growth model. The basic model in this growth model is:

$$
Y=F(K, L)
$$

where $\mathrm{Y}$ is output, $\mathrm{K}$ is capital, and $\mathrm{L}$ is the labor force. By dividing both sides with $\mathrm{L}$, we will get

$$
y=f(k)
$$

where $\mathrm{y}$ is output per worker and capital is per worker.

Based on this model, economic growth depends on capital growth and population growth. Because capital growth is affected by the formation of capital savings and depreciation, in a certain period, capital growth will become zero. This happens because the value of capital that is formed and depreciated is the same. Therefore the economy will reach a stable condition with a steady income. The inclusion of technological developments in neoclassical models is difficult, because standard competitive assumptions cannot be maintained. The endogenous model offers an explanation of technological developments by incorporating technological developments into the model. The basic model for endogenous growth models is as follows:

$$
Y=f(K, L, A)
$$

Where $\mathrm{K}$ is capital (including human resources) and A represents the development of technological progress. In this model, scale of return may not be constant, depending on technological development. Therefore the economy will enjoy positive economic growth as long as their technology develops. In this model, the sharing of knowledge between producers and benefits of human resources is part of the process. In the Solow model, technology is assumed not to be influenced by $\mathrm{K}$ and $\mathrm{L}$, meaning that changes in stock $\mathrm{K}$ and $\mathrm{L}$ are not affected by technological progress. In other words, technology is assumed to be exogenous in the Solow model and is determined by things outside the model and not influenced by other variables in the model; technology changes just happen without explanation. In essence, the production function is described as being at a certain level of technology and a certain level of supply. This makes us focus more on how output is related to capital input, technology and certain labor. The production function indicates the amount of output produced with the level of capital input $(\mathrm{K})$ different from certain $\mathrm{L}$ and $\mathrm{A}$. In the long-term output depends on the level of capital stock in the economy.

\section{Result and Discussion}

Description of the discussion of the effect of capital formation on Gross Domestic Product through a quantitative approach that uses the calculation of the regression model is intended to analyze the relationship / influence between the dependent variable (Gross Domestic Product) and the independent variable (Gross Capital Formation) and to know the extent and direction of the relationship the variable. While the correlation analysis is used to find out how much the degree / degree of closeness between the variables that exist, in this study the author uses Shazam Software version 9.0 Regression model of Gross Domestic Product is obtained the following regression equation:

$$
L_{n} P D B_{i}=1,8428+0,99639 L_{n} G C F_{i}+e_{i}
$$

where Gross Capital Formation towards Gross Domestic Product. 


\section{Conclusion}

Based on the results of the research, some conclusions can be drawn toward Gross Domestic Product:. Gross Capital Formation has a positive relationship to Gross Domestic Product where if the Gross Capital Formation increases one percent, the Gross Domestic Product will increase by 0.99639 percent (ceteris paribus).

\section{Referencees}

[1] www.elsevier.com/locate/worlddev 2017

[2] Marcio Cruz, Amer Ahmed

[3] On the impact of demographic change on economic growth and poverty

[4] www.elsevier.com/locate/worlddev 2017

[5] Susanne A. Frick, Adres Rodriguez-Pose Change in urban concentration and economic growth

[6] www.elsevier.com/locate/physa 2017

[7] Raphael H. Heiberger Predicting economic growth with stock networks

[8] www.elsevier.com/locate/intfin 2018

[9] Marta Gomez-puig, Simon Sosvilla-Rivero Nonfinancial debt and economic growth in euro-area countries

[10] www.elsevier.com/locate/irfa 2017

[11] Jittima Tongurai, Chaiporn Vithessonthi The impact of the banking sector on economic structure and growth

[12] www.elsevir.com/locate/ecolet 2017

[13] Emmanouil Gkiourkas Theodore Panagiotidis, Gianluigi Pelloni revitising the macroeconomic effects of labor reallocation

[14] www.elsevier.com/locate/ecolet 2018

[15] vaibhav Lalwani, madhumita chakraborty asset pricing factors and future economic growth

[16] www.elsevier.com/locate/ribaf 2017

[17] Dai-won kim, Jung-suk Yu, M.kabir Hassan Financial inclusion and economic growth in OIC countries

[18] hhtp://doi.org/10.1016/j.asleco.2017.12.008 2018

[19] Markus Brueckner, Era Dabla-Norris, Mark gradstein, Daniel Lederman the rise of the middle class and economic growth in ASEAN

[20] www.elsevier.com/locate/iref 2017

[21] Jose 1.Ruiz financial development, institutional investors, and economic growth

[22] www.elsevier.com/locate/jbee 2018

[23] Maria Thompson social capital,innovation and economic growth 